\title{
MENINGKATKAN KEMAMPUAN ANALISIS MATEMATIS MAHASISWA PADA MATA KULIAH KAJIAN PEMBELAJARAN MATEMATIKA MODERN MELALUI PEMBELAJARAN KOLABORATIF MURDER (Studi Kuasi Eksperimen terhadap Mahasiswa Tadris Matematika IAIN Syekh Nurjati Cirebon)
}

\author{
Nurma Izzati \\ Tadris Matematika, IAIN Syekh Nurjati Cirebon \\ Jl. Perjuangan No.1 By Pass Sunyaragi Cirebon \\ izzah_tiar@yahoo.com
}

\begin{abstract}
Penelitian ini bertujuan untuk menelaah perbedaan peningkatan kemampuan analisis matematis antara mahasiswa yang memperoleh pembelajaran kolaboratif MURDER dengan mahasiswa yang memperoleh pembelajaran konvensional pada mata kuliah Kajian Pembelajaran Matematika Modern, serta untuk mengetahui respon mahasiswa terhadap pembelajaran kolaboratif MURDER. Metode penelitian yang digunakan dalam penelitian ini adalah metode kuasi eksperimen dengan disain penelitian yang digunakan adalah pretest posttest control group design. Kelas eksperimen memperoleh pembelajaran kolaboratif MURDER dan kelas kontrol memperoleh pembelajaran konvensional. Untuk mendapatkan data hasil penelitian digunakan instrumen berupa tes kemampuan analisis matematis dan angket respon mahasiswa. Penelitian dilakukan di IAIN Syekh Nurjati Cirebon pada semester ganjil tahun akademik 2015/2016. Populasi penelitian ini adalah seluruh mahasiswa jurusan Tadris Matematika IAIN Syekh Nurjati Cirebon dengan sampel penelitian adalah seluruh mahasiswa jurusan Tadris Matematika yang mengambil mata kuliah Kajian Pembelajaran Matematika Modern, dengan kelas A sebagai kelas kontrol dan kelas B sebagai kelas eksperimen yang masing-masing berjumlah 38 orang mahasiswa. Analisis data dilakukan terhadap rerata gain ternormalisasi kedua kelompok sampel. Hasil penelitian menunjukkan bahwa peningkatan kemampuan analisis matematis mahasiswa yang memperoleh pembelajaran kolaboratif MURDER lebih tinggi daripada peningkatan kemampuan analisis matematis mahasiswa yang memperoleh pembelajaran konvensional. Analisis data angket respon mahasiswa menunjukkan bahwa sebagian besar mahasiswa memberikan respon positif terhadap pembelajaran kolaboratif MURDER.
\end{abstract}

Keywords: Analisis, Matematis, Kolaboratif, MURDER

\section{PENDAHULUAN}

\section{Latar Belakang}

Kemampuan analisis merupakan kemampuan tingkat tinggi yang memerlukan penalaran lebih mendalam terhadap suatu permasalahan. Kemampuan analisis sangat diperlukan dalam menyelesaikan permasalahan- permasalahan dalam kehidupan sehari-hari. Namun kemampuan analisis peserta didik masih rendah, hal ini karena sistem pendidikan kita yang sebagian besar masih berorientasi pada kemampuan tingkat rendah, yaitu menghafal dan mencatat, drill and practice. Hal ini bisa terlihat dari kebanyakan peserta didik mampu mengerjakan soal-soal rutin, namun mengalami kesulitan dalam menyelesaikan 
soal-soal yang membutuhkan kemampuan lebih, seperti melakukan analisis.

Mata kuliah Kajian Pembelajaran Matematika Modern merupakan mata kuliah yang mengkaji lebih dalam permasalahan dan isu-isu terkini dalam pembelajaran matematika. Pada mata kuliah ini mahasiswa dituntut untuk mampu melakukan analisis, mengkaji dan mencari solusi dari permasalahanpermasalahan yang sedang dibahas.

Dalam proses pembelajaran di kelas, suasana hati (mood) peserta didik juga jarang diperhatikan, guru hanya berorientasi pada menyampaikan materi tanpa memperhatikan suasana hati peserta didik apakah sudah siap belajar atau tidak. Membangun mood belajar peserta didik sangat penting dilakukan agar proses pembelajaran berjalan optimal. Jika peserta didik sudah siap untuk belajar, diharapkan mereka mampu belajar dengan baik, memahami materi dengan baik sehingga hasil belajarnya meningkat.

Untuk itulah perlu adanya upaya untuk meningkatkan kemampuan analisis peserta didik dengan berorientasi pada membangun mood peserta didik agar siap untuk belajar, salah satunya adalah dengan menerapkan pembelajaran kolaboratif MURDER (mood, understand, recall, digest, expand, and review), yaitu pembelajaran berkelompok yang menekankan pada proses untuk belajar bersama, berkembang bersama dan mencapai tujuan bersama.

Berdasarkan pemaparan di atas, maka diharapkan pembelajaran kolaboratif MURDER dapat meningkatkan kemampuan analisis matematis mahasiswa khusus pada mata kuliah Kajian Pembelajaran Matematika Modern.

\section{Rumusan Masalah}

Berdasarkan latar belakang yang telah diuraikan, rumusan masalah dalam penelitian ini adalah:

1. Apakah peningkatan kemampuan analisis matematis mahasiswa yang memperoleh pembelajaran kolaboratif MURDER lebih tinggi daripada peningkatan kemampuan analisis matematis mahasiswa yang memperoleh pembelajaran konvensional?

2. Bagaimana respon mahasiswa terhadap pembelajaran kolaboratif MURDER yang dilaksanakan?

\section{Tujuan Penelitian}

Penelitian ini bertujuan untuk:

1. Menelaah peningkatan kemampuan analisis matematis mahasiswa yang memperoleh pembelajaran kolaboratif MURDER bila dibandingkan dengan peningkatan kemampuan analisis matematis mahasiswa yang memperoleh pembelajaran konvensional.

2. Mengetahui bagaimana respon mahasiswa terhadap pembelajaran kolaboratif MURDER yang dilaksanakan.

\section{Hipotesis Penelitian}

Hipotesis dalam penelitian ini adalah: Peningkatan kemampuan analisis matematis mahasiswa yang memperoleh pembelajaran kolaboratif MURDER lebih tinggi daripada peningkatan kemampuan analisis matematis mahasiswa yang memperoleh pembelajaran konvensional.

\section{KAJIAN PUSTAKA}

\section{Kemampuan Analisis Matematis}

Matematika menurut Elea Tinggih (Erman Suherman, dkk., 2003) merupakan ilmu pengetahuan yang diperoleh dengan bernalar. Analisis menurut Nana Sudjana (2002) adalah kesanggupan memecah, mengurai suatu integritas (kesatuan yang utuh) menjadi unsur-unsur atau bagianbagian yang mempunyai arti atau mempunyai tingkatan/hirarki. Analisis merupakan tipe hasil belajar yang kompleks, yang memanfaatkan hasil belajar sebelumnya, yakni pengetahuan, 
pemahaman, aplikasi. Bila kemampuan analisis telah dimiliki seseorang, maka seseorang dapat mengkreasikan sesuatu yang baru. Bloom dalam Suharsimi Arikunto (2002) membagi aspek analisis ke dalam tiga kategori, yaitu: 1) analisis bagian (unsur) seperti melakukan pemisalan fakta, unsur yang didefinisikan, argumen, aksioma (asumsi), dalil, hipotesis, dan kesimpulan; 2) analisis hubungan (relasi) seperti menghubungkan antara unsur-unsur dari suatu sistem (struktur) matematika; 3) analisis sistem seperti mampu mengenal unsur-unsur dan hubungannya dengan struktur yang terorganisirkan. Penjabaran dari ketiga kategori tersebut menurut Suharsimi Arikunto (2002) meliputi berbagai keterampilan, yaitu: memperinci, mengasah diagram, membedakan, mengidentifikasi, mengilustrasi, menyimpulkan, menunjukkan, dan membagi.

Suherman dan Sukjaya (1990) menyatakan bahwa kemampuan analisis adalah kemampuan untuk merinci atau menguraikan suatu masalah (soal) menjadi bagian-bagian yang lebih kecil (komponen) serta mampu untuk memahami hubungan diantara bagian-bagian tersebut. Dalam kemampuan analisis ini juga termasuk kemampuan menyelesaikan soal-soal yang tidak rutin, menemukan hubungan, membuktikan dan mengomentari bukti, dan merumuskan serta menunjukkan benarnya suatu generalisasi, tetapi baru dalam tahap analisis belum dapat menyusun. Kemampuan analisis yang dapat diukur adalah kemampuan mengidentifikasi masalah, kemampuan menggunakan konsep yang sudah diketahui dalam suatu permasalahan dan mampu menyelesaikan suatu persoalan dengan cepat.

Berdasarkan pernyataan di atas, maka dapat disimpulkan bahwa kemampuan analisis matematis adalah kemampuan bernalar untuk menguraikan suatu masalah dengan melakukan identifikasi masalah, menggunakan konsep yang sudah diketahui dan mampu menyelesaikannya dengan cepat.

\section{Pembelajaran Kolaboratif MURDER}

Kolaboratif berbeda dengan kooperatif. John Myers (1991) menjelaskan definisi collaboration yang berasal dari akar kata Latin dengan makna yang menitikberatkan pada proses kerjasama, sedangkan kata cooperation berfokus pada produk kerjasama itu. Pembelajaran kolaboratif menurut Gerlach (1994) menyatakan bahwa "collaborative learning is a process that involves interaction among individuals in a learning situation. It is rooted in a theory of learning the focuses on social interaction as a way to building knowledge". Sedangkan Wiersema (2000) menyatakan bahwa "collaborative Lerning is philosophy: working together, building together, learning together, changing together, improving together".

Pembelajaran MURDER merupakan pembelajaran yang diadaptasi dari buku karya Bob Nelson "The Complete Problem Solver". MURDER merupakan gabunan dari kata-kata: Mood, Understand, Recall, Digest, Expand, dan Review. Langkah-langkah penerapan pembelajaran kolaboratif MURDER adalah sebagai berikut:

1. Mood, yaitu menciptakan suasana hati (mood) yang baik untuk beelajar sehingga peserta didik termotivasi untuk semangat, siap, dan konsentrasi dalam belajar.

2. Understand, yaitu memberikan pemahaman terhadap konsep-konsep atau materi yang dipelajari;

3. Recall, yaitu melakukan pengulangan kembali materi yang telah dipahami.

4. Digest, yaitu menelaah lebih dalam materi atau pengetahuan yang telah dipelajari;

5. Expand, yaitu mengembangkan pengetahuan yang didapat dengan menghubungkannya dengan pengetahuan-pengetahuan lain yang terkait.

6. Review, yaitu mempelajari kembali materi yang telah dipelajari dan pahami.

Berdasarkan uraian di atas, dapat disimpulkan bahwa pembelajaran 
kolaboratif MURDER adalah pembelajaran berkelompok yang menitikberatkan pada proses dengan prinsip belajar bersama untuk mencapai tujuan bersama dengan menerapkan langkah-langkah pembelajaran MURDER.

\section{METODE PENELITIAN}

\section{Populasi dan Sampel Penelitian}

Populasi penelitian ini adalah seluruh mahasiswa jurusan Tadris Matematika IAIN Syekh Nurjati Cirebon pada semester ganjil tahun akademik 2015/2016 dengan sampel penelitian adalah seluruh mahasiswa jurusan Tadris Matematika yang mengambil mata kuliah Kajian Pembelajaran Matematika Modern, yang terdiri dari 2 kelas: A dan B, dengan kelas A sebagai kelas kontrol dan kelas B sebagai kelas eksperimen yang masing-masing berjumlah 38 orang mahasiswa. Kedua kelas tersebut mempunyai karakteristik dan kemampuan akademik yang setara, serta diampu oleh dosen yang sama. Pertimbangan-pertimbangan tersebut diambil untuk meminimalisir perbedaanperbedaan antara kedua kelas (kontrol dan eksperimen) yang dibandingkan.

\section{Metode dan Disain Penelitian}

Metode penelitian yang digunakan dalam penelitian ini adalah metode kuasi eksperimen yaitu metode yang tidak memungkinkan peneliti melakukan pengontrolan penuh terhadap variabel dan kondisi eksperimen. Desain yang digunakan dalam penelitian ini adalah pretest postest control group design. Desain penelitian ini digunakan karena penelitian ini menggunakan kelas kontrol dan adanya dua perlakuan yang berbeda. Dalam penelitian ini ada dua kelas yang dibandingkan dengan memberikan perlakuan yang berbeda. yaitu kelas eksperimen memperoleh pembelajaran kolaboratif MURDER dan kelas kontrol memperoleh pembelajaran konvensional. Kedua kelas ini diberi pretes sebelum pembelajaran dan postes setelah pembelajaran.

Variabel bebas dalam penelitian ini adalah penerapan pembelajaran kolaboratif MURDER, sedangkan variabel terikatnya adalah kemampuan analisis matematis mahasiswa pada mata kuliah Kajian Pembelajaran Matematika Modern.

\section{Instrumen Penelitian}

Untuk memperoleh data dalam penelitian ini, digunakan dua macam instrumen, yaitu: a) soal tes untuk mengetahui kemampuan analisis matematis mahasiswa dalam bentuk soal uraian sebanyak 5 butir soal; dan b) angket sebanyak 25 butir pernyataan untuk mengetahui respon mahasiswa terhadap penerapan pembelajaran kolaboratif MURDER. Soal tes untuk mengukur kemampuan analisis matematis mahasiswa disusun berdasarkan indikator kemampuan analisis matematis. Soal tes diujicobakan terlebih dahulu untuk mengetahui validitas, reliabilitas, daya pembeda dan tingkat kesukarannya.

Hasil uji coba menunjukkan bahwa seluruh butir soal valid dan dapat digunakan untuk mengukur kemampuan analisis matematis mahasiswa dengan reliabilitas 0,72 termasuk kategori tinggi. Taraf kesukaran soal terdiri dari: 1 soal mudah, 3 soal sedang dan 1 soal sukar dan semua soal mempunyai daya pembeda yang baik.

\section{Alur Pengolahan data}

Data yang diperoleh dari hasil tes diolah melalui tahap-tahap sebagai berikut:

1. Melakukan uji normalitas untuk mengetahui apakah data berasal dari 
populasi yang berditribusi normal atau tidak.

2. Menguji homogenitas varians data untuk mengetahui apakah data homogen atau tidak.

3. Menguji hipotesis penelitian untuk mengetahui apakah hipotesis penelitian ditolak atau diterima.

Semua pengolahan data menggunakan bantuan software SPSS 17.0 dan Microsoft Office Excel 2010.

\section{HASIL DAN PEMBAHASAN}

\section{Deskripsi Hasil Tes}

Setelah dilakukan pengolahan data skor pretes dan postes dengan menggunakan bantuan Microsoft Office Excel 2010 dan Program SPSS versi 17.0 diperoleh hasil sebagai berikut:

Tabel 1. Rerata Pretes dan Postes Kemampuan Analis Matematis Mahasiswa

\begin{tabular}{|c|c|c|}
\hline $\begin{array}{c}\text { Kelas/Kelompo } \\
\mathbf{k}\end{array}$ & $\begin{array}{c}\text { Prete } \\
\mathbf{s}\end{array}$ & Postes \\
\hline Eksperimen & 9,95 & 71,63 \\
\hline Kontrol & 9,72 & 45,76 \\
\hline
\end{tabular}

Dari Tabel 1, di atas terlihat bahwa rerata skor pretes kemampuan analisis matematis mahasiswa kelas eksperimen tidak terlalu berbeda dengan skor prestes kemampuan analisis matematis mahasiswa kelas kontrol yang memperoleh pembelajaran konvensional. Hal ini menunjukkan bahwa kemampuan analisis matematis mahasiswa kedua kelas sampel sebelum mendapat perlakuan homogen. Sedangkan rerata skor postes kemampuan analisis matematis mahasiswa kelas eksperimen menunjukkan hasil yang lebih tinggi dibandingkan dengan kelas kontrol.

Untuk melihat peningkatan kemampuan analisis matematis yang telah dicapai oleh mahasiswa dan kualifikasinya digunakan data gain ternormalisasi yang diformulasikan oleh Hake (1999). Rerata gain ternormalisasi merupakan gambaran peningkatan kemampuan analisis matematis mahasiswa.
Tabel 2. Rerata Gain

Kemampuan Analisis Matematis Mahasiswa

\begin{tabular}{|c|c|c|c|}
\hline $\begin{array}{c}\text { Kelas/ } \\
\text { Kelompok }\end{array}$ & N & $\overline{\boldsymbol{x}}$ & $\begin{array}{c}\text { Kualifikasi } \\
\text { Gain }\end{array}$ \\
\hline Eksperimen & 38 & 0,68 & Sedang \\
\hline Kontrol & 38 & 0,39 & Sedang \\
\hline
\end{tabular}

Dari Tabel 2 di atas, terlihat bahwa kemampuan analisis matematis mahasiswa kelas eksperimen yang memperoleh pembelajaran kolaboratif MURDER memiliki rerata gain yang lebih tinggi daripada rerata gain mahasiswa kelas kontrol yang memperoleh pembelajaran konvensional dengan kualifikasi kedua data gain termasuk kategori sedang. Hal ini menunjukkan bahwa peningkatan kemampuan analisis matematis mahasiswa kelas eksperimen lebih tinggi daripada peningkatan kemampuan analisis matematis mahasiswa kelas kontrol.

Selanjutnya untuk mengetahui apakah perbedaan peningkatan kemampuan analisis matematis mahasiswa antara kelas eksperimen dan kelas kontrol berbeda secara signifikan, perlu dilakukan uji perbedaan dua rerata. Namun, sebelumnya terlebih dahulu dilakukan uji normalitas dan uji homogenitas terhadap gain pada kedua kelompok data tersebut, yaitu data dari kelas eksperimen dan kelas kontrol.

Uji normalitas dilakukan untuk mengetahui apakah data berasal dari populasi yang berdistribusi normal atau tidak. Uji statistik yang akan digunakan adalah uji Kolmogrov-Smirnov dengan mengambil taraf signifikan (a) sebesar 5\% dengan hipotesis sebagai berikut:

$\mathrm{H}_{0}$ : Data gain kemampuan analisis matematis mahasiswa berasal dari populasi yang berdistribusi normal

$\mathrm{H}_{1}$ : Data gain kemampuan analisis matematis mahasiswa berasal dari populasi yang tidak berdistribusi normal

Kriteria pengujiannya adalah: H0 diterima jika nilai signifikan (Sig) $>0,05$ dan H0 ditolak jika nilai signifikan (Sig) $<0,05$. 
Berdasarkan hasil perhitungan untuk pengujian normalitas data gain kemampuan analisis matematis mahasiswa yang memperoleh pembelajaran kolaboratif MURDER dengan uji Kolmogorov-Smirnov menggunakan program SPSS 17.0 didapat nilai signifikansi 0,74 . Nilai signifikansi 0,74 $>0,05$, maka H0 diterima. Sedangkan berdasarkan perhitungan untuk pengujian normalitas data gain kemampuan analisis matematis mahasiswa yang memperoleh pembelajaran konvensional dengan uji Kolmogorov-Smirnov menggunakan program SPSS 17.0 didapat nilai signifikansi 0,37 . Nilai signifikansi $0,37>$ 0,05 , maka H0 diterima. Sehingga dapat disimpulkan bahwa kedua data gain kemampuan analisis matematis mahasiswa berasal dari populasi yang berdistribusi normal.

Uji homogenitas dilakukan untuk mengetahui apakah varians kedua data homogen atau tidak. Uji statistik yang akan digunakan adalah uji Levene dengan mengambil taraf signifikan (a) sebesar 5\% dengan hipotesis sebagai berikut:

$\mathrm{H}_{0}$ : Kedua data gain memiliki varians yang homogen

$\mathrm{H}_{1}$ : Kedua data gain memiliki varians yang tidak homogen

Kriteria pengujiannya adalah: $\mathrm{H} 0$ diterima jika nilai signifikan ( $\mathrm{Sig}$ ) $>0,05$ dan H0 ditolak jika nilai signifikan (Sig) $<0,05$.

Berdasarkan hasil perhitungan untuk pengujian homogenitas data gain kemampuan analisis matematis mahasiswa kelas eksperimen dan kelas kontrol dengan uji Levene menggunakan program SPSS 17.0 didapat nilai signifikansi 0,68 . Nilai signifikansi 0,68 > 0,05, maka H0 diterima. Sehingga dapat disimpulkan bahwa kedua kelompok data gain kelas eksperimen dan kontrol memiliki varians yang homogen.

Setelah dilakukan uji normalitas dan uji homogenitas terhadap data gain pada kedua kelompok, menunjukkan hasil bahwa data kelompok gain kelas eksperimen dan kelas kontrol mempunyai varians yang homogen dan keduanya berasal dari populasi yang berdistribusi normal. Selanjutnya untuk mengetahui signifikansi perbedaan rerata peningkatan kedua kelompok data dilakukan uji perbedaan dua rerata dengan mengambil taraf signifikan (a) sebesar 5\%. dengan hipotesis sebagai berikut:

$\mathrm{H}_{0}$ : Peningkatan kemampuan analisis matematis mahasiswa yang memperoleh pembelajaran kolaboratif MURDER lebih rendah atau sama dengan peningkatan kemampuan analisis matematis mahasiswa yang memperoleh pembelajaran konvensional.

$\mathrm{H}_{1}$ : Peningkatan kemampuan analisis matematis mahasiswa yang memperoleh pembelajaran kolaboratif MURDER lebih tinggi daripada peningkatan kemampuan analisis matematis mahasiswa yang memperoleh pembelajaran konvensional.

Kriteria pengujiannya adalah: H0 diterima jika nilai signifikan (Sig) $>0,05$ dan $\mathrm{H0}$ ditolak jika nilai signifikan (Sig) < 0,05 .

Berdasarkan hasil perhitungan uji perbedaan dua rerata gain yang dilakukan dengan bantuan Program SPSS versi 17.0, diperoleh hasil sebagai berikut:

Tabel 3.Uji Perbedaan Rerata Gain Kemampuan Analisis Matematis Mahasiswa

\begin{tabular}{|c|c|c|c|}
\hline & $\mathbf{t}$ & $\mathbf{d f}$ & Sig. \\
\hline $\begin{array}{c}\text { Equal variances } \\
\text { assumed }\end{array}$ & 7,19 & 74 & 0.00 \\
\hline
\end{tabular}

Dari Tabel 3 di atas, diperoleh p-value (Sig) perbedaan rerata peningkatan kemampuan analisis matematis mahasiswa kelas eksperimen dan mahasiswa kelas kontrol adalah $0,00<0,05$, maka hipotesis H0 ditolak. Sehingga dapat disimpulkan bahwa peningkatan kemampuan analisis matematis mahasiswa yang memperoleh pembelajaran kolaboratif MURDER lebih tinggi daripada peningkatan kemampuan analisis matematis mahasiswa yang 
memperoleh pembelajaran konvensional pada taraf signifikansi $5 \%$.

Hasil dari penyebaran angket respon kepada mahasiswa kelompok eksperimen yang memperoleh pembelajaran kolaboratif MURDER diperoleh temuan bahwa sebagian besar mahasiswa memberikan respon positif terhadap pembelajaran kolaboratif MURDER.

\section{KESIMPULAN DAN SARAN}

\section{Kesimpulan}

Berdasarkan hasil penelitian dan pembahasan diperoleh kesimpulan bahwa:

1. Peningkatkan kemampuan analisis matematis mahasiswa yang memperoleh pembelajaran kolaboratif MURDER lebih tinggi daripada peningkatan kemampuan analisis matematis mahasiswa yang memperoleh pembelajaran konvensional.

2. Sebagian besar mahasiswa memberikan respon positif terhadap penerapan pembelajaran kolaboratif MURDER.

\section{Saran}

1. Bagi para pendidik, pembelajaran kolaboratif MURDER dapat dijadikan sebagai salah satu alternatif metode pembelajaran untuk meningkatkan kemampuan analisis matematis dengan mengoptimalkan suasana hati (mood) dan kemampuan peserta didik, sehingga diharapkan hasil belajarnya meningkat.

2. Bagi peneliti berikutnya agar:

$>$ Memperhatikan pembagian kelompok dan pembagian peran atau tugas masing-masing anggota kelompok, karena dalam pembelajaran kolaboratiif pembagian kelompok dan tugas masingmasing anggota yang tepat dapat lebih memaksimalkan hasil belajar.

Aktifitas membangun mood peserta didik harus benar-benar dioptimalkan, karena mood sangat mempengaruhi keberhasilan dalam pembelajaran kolaboratif MURDER.

\section{DAFTAR PUSTAKA}

Arikunto, Suharsimi. 1986. Pengelolaan Kelas dan Siswa. Jakarta: CV. Rajawali.

Arikunto, Suharsimi. 2002. Dasar-dasar Evaluasi Pendidikan. Jakarta: Bumi Aksara.

Gerlach, J. M. 1994. Is this collaboration? In Bosworth, K. \& Hamilton, S. J. (Eds.), Collaborative Learning: Underlying Processes and Effective Techniques, New Directions for Teaching and Learning, No. 59. San Francisco; USA, Jossey-Bass Publishing.

Hake, R. R. 1999. Analyzing Change/Gain Scores. [ONLINE]. Tersedia: http://www.physics. indiana.edu/ sdi/AnalyzingchangeGain.pdf. [20-12-2014].

Hudojo, Herman. 1988. Mengajar Belajar Matematika. Jakarta: Depdikbud.

Myers, John. 1991. Collaborative Learning: What is Collaborative Learning [ONLINE]. Tersedia: http://www.londonmet.ac.uk/deliber ations/ collaborative-learning/panitzpaper.cfm. [08-12-2014].

Reid. 2004. Enhancing Student thinking through Collaboration Learning. [[ONLINE]. Tersedia: http//www.ed.gov/database/ERIC_Di gest. [08-12-2014]. 
Sudjana, Nana. 2002. Penilaian Hasil Proses Belajar Mengajar. Bandung: Remaja Rosdakarya.

Sugihartono, dkk. 2012. Psikologi Pendidikan. Yogyakarta: UNY Press.

Suherman, E. dan Sukjaya, Y. 1990. Petunjuk Praktis untuk Melaksanakan Evaluasi Pendidikan Matematika.

Bandung: Wijayakusumah 157.

Suherman, Erman, dkk. 2003. Strategi Pembelajaran

Matematika
Kontemporer. Bandung: Jurusan Matematika, FMIPA, UPI.

Trianto. 2010. Mendesain Model Pembelajaran Inovatif-Progresif. Jakarta: Kencana.

Wiersema, N. 2000. How Does Collaborative Learning Actually Work in Classroom and How Do Students React to It? [ONLINE]. Tersedia: http://www.city.londonmet.ac.uk/deli berations/collab.learning/wiersema. html. [08-12-2014]. 